\title{
Late Paleozoic Subduction 7 and Accretion in Southern Chile
}

\author{
by Francisco Hervé
}

The Coast Ranges of southern Chile are underlain for the most part by a variably metamorphosed subduction complex of late Paleozoic age. In a contribution to IGCP 279, "Terranes in Latin America," the author reviews the depositional and metamorphic development of this huge accretionary unit developed in the Gondwana continental margin. South to north transport of the accreted material parallel to the continental margin may prove to have been an important tectonic process in the region. (Ed.)

\section{Introduction}

A main portion of the Coast Ranges of Chile, south of $34^{\circ} \mathrm{S}$, is underlain by igneous and metamorphic complexes. The metamorphic rocks have been considered to be Precambrian (Ruiz, 1965) and were represented as such in the $1: 5,000,000$ geological map of South America (Harrington, 1962). However, during the late 1960 s and early 1970 s, these complexes were shown to have conspicuous metamorphic and structural zoning (González-Bonorino, 1971; González-Bonorino and Aguirre, 1970), as in the paired metamorphic belts of Miyashiro (1961). At the same time, radiometric dating of the complexes failed to yield ages older than Carboniferous (Munizaga, 1967; Munizaga et al., 1973; Hervé et al., 1974). Even though the meaning in terms of the geological events they represented was not absolutely clear, both $\mathrm{Rb}-\mathrm{Sr}$ whole rock isochrons and $\mathrm{K}-\mathrm{Ar}$ dating on amphiboles were interpreted as ages of metamorphism, and little could then be said about the age of the protolith.

The associated granitoids were indicated as Cretaceous in the $1: 1,000,000$ geological map of Chile (Anon, 1960), but radiometric dating (Muñoz-Cristi, 1964; Hervé et al., 1976a) provided convincing evidence that the granitoids were also emplaced during the Carboniferous. These findings led to the conviction that very important tectonic and petrogenetic processes had taken place during the late Paleozoic in this continental margin of Gondwana.

This paper presents a synthesis of lithologic, structural, mineralogic and chronological data on the metamorphic complexes and interprets their mode of origin and emplacement within the conceptual framework of plate tectonies. For descriptive purposes the area will be divided from north to south into the Pichilemu area, the Nahuelbuta mountains, the Temuco-Chiloé area, the Chonos Archipelago, the Madre de Dios Archipelago and Cordillera Darwin (Fig. 1).

\section{Lithology}

The metamorphic rocks of southern Chile are dominantly turbidite sequences and their metamorphic equivalents (phyllite and mica schist), which constitute vast areas in the westernmost outcrops, and have a characteristic spotted appearance, black albite porphyroblasts being very abundant in them. Some mica schists are rich in graphitic material, and are spatially related to gold-bearing bodies within the schists (Zuccone, personal communication, 1988). Primary sedimentary structures are well preserved in the more easterly portions of the complex, in particular in the Nahuelbuta Mountains and the Chonos Archipelago. The turbidite sequences in the latter display prominent graded bedding, sedimentary lamination, and occasional grooved base structures (Fig. 2). Thick sandy units exist at Patranca and neighbouring islands.

The Chonos Archipelago is also characterized by the presence of widespread mélanges. Turbidite sequences are discupted tectonically (Fig. 3) and contain a few exotic clasts of meta-igneous origin up to several metres long (Garrido, 1987). Mélanges are well recognized only in the eastern low-grade areas. However, because schists formed with mélanges as a protolith are indistinguishable from other schists, mélanges may have been originally more abundant than presently recognized.

Meta-basalts are widespread, mostly as greenschist, but also greenstones with pillow structures are present (Figs. 1 and 4). Geochemical studies of these meta-basites (Hervé, 1977; Hervê et al., 1976b; Godoy, 1979, 1980, 1986) indicate that they have geochemical characteristics similar to those of modern ocean floor basalts.

Meta-cherts are also common, many being iron rich, with $\mathrm{Fe}$ grades up to $40 \%$ at the Mahuilque deposits $\left(38^{\circ} \mathrm{S}\right)$, containing several million tons of ore. A possible environment for the deposition of meta-chert is indicated by the Madre de Dios outcrops, where metalliferous red cherts directly overlie pillow basalts and are overlain in turn by radiolarian rich green cherts (Forsythe and Mpodozis, 1979). Geochemistry of the latter and of those ribbon cherts interbedded with the turbidite sequences at the Chonos Archipelago (Fig. 5) are not incompatible with deposition in a region affected by ocean ridge hydrothermal processes.

Limestone and its metamorphic equivalents are very rare in the complex, with the main outcrops at the northwestern shore of Lago General Carrera, and at the Madre de Dios Archipelago. Forsythe and Mpodozis (1983) concluded that the latter were deposited in an oceanic island free from detrital continental influence. Probably the same environment produced the Lago General Carrera marbles, presently the site of important $\mathrm{Pb}, \mathrm{Zn}, \mathrm{Cu}$ and $\mathrm{Ag}$ mineralization related to the intrusion of Late Cretaceous plutons into the metamorphic complex.

Serpentinite bodies metres to several kilometres in length are common in parts of the complex, in particular between 38 and $41^{\circ} \mathrm{S}$. They seem to have been tectonically emplaced into the surrounding schists during an early stage of metamorphism. They contain no relic silicate minerals, but in some of them podiform lenses and veinlets of chromite or chromite + pyrrotite + pentlandite are found. The ultra- 
mafic igneous rock parentage is also clearly indicated by bastite structure of the antigorite. Some have breccia structures that can be interpreted as mélanges (Gana and Hervé, 1983),

Limited major element chemistry data (Ojeda, 1976) indicate $\mathrm{Al}$ contamination by the host rocks. Nb-Sm studies on the Quitratue serpentinite indicate values characteristic of depleted harzburgitic rocks, which are comparable to mantle beneath active mid-ocean ridges. Sulphide pods and layers, usually hosted by greenschist, constitute volumetrically minor but well-distributed component of the metamorphic complex. They are composed of pyrite-pyrrhotite-sphalerite-chalcopyrite aggregates (Collao et al., 1986) with minor mackonawite, galena and bornite.
The meta-basites may have been derived from the ocean floor, at spreading ridges (Hervé et al., 1976b, Godoy, 1986), from intraoceanic volcanic are material, or from isolated oceanic islands or guyots (Forsythe and Mpodozis, 1979). Metalliferous sediments as well as massive sulphides deposited over basaltic material is a characteristic of near-ridge environments. The extremely long extension of the complex along the present coast of South America (2500 $\mathrm{km}$, see Fig. 1 of Ramos, this issue) allows enough space for all of these different tectonic settings.

\section{Metamorphism}

Metamorphic grade varies from east to west across the belt but has some remarkably constant features along it. A

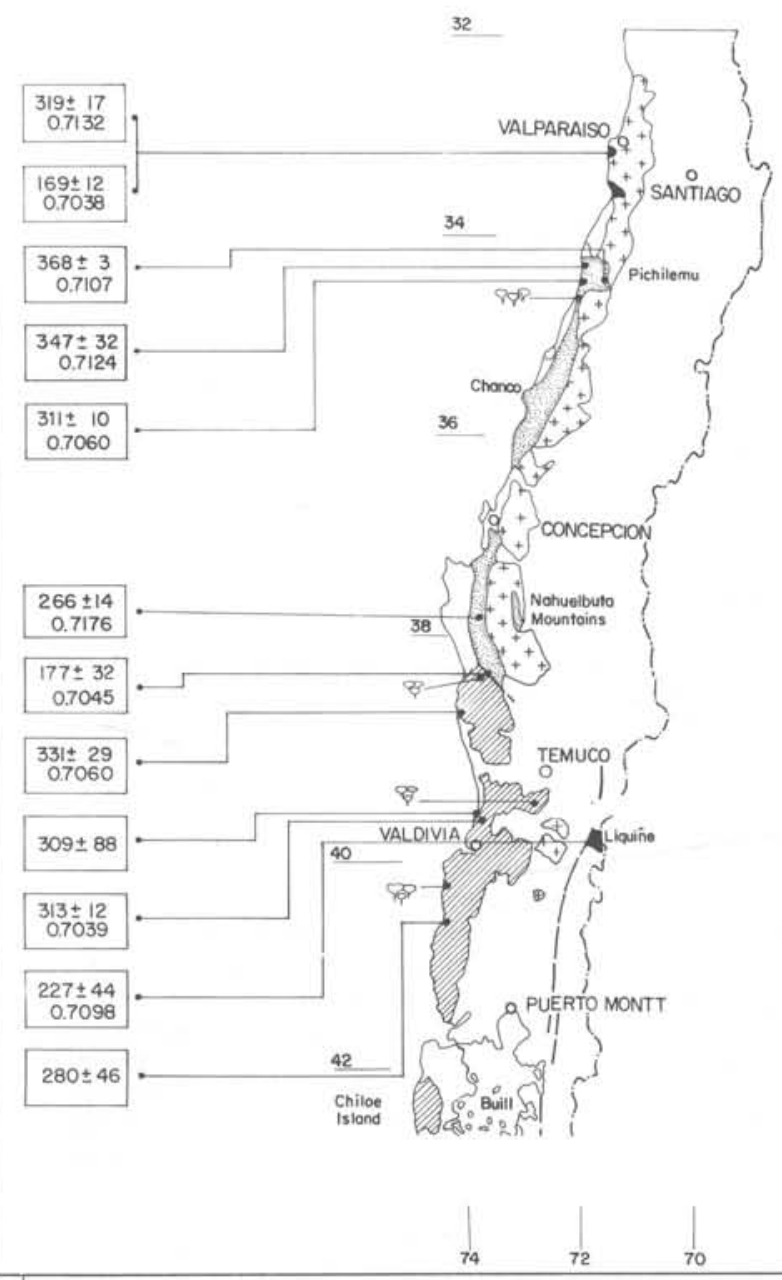

Figure 1: The metamorphic and plutonic complexes of the Andes south of $34^{\circ} \mathrm{S}$, showing $R b-S r$ whole rock isochron dates.

The lithology of the metamorphic complex indicates that its protolith was generated in an oceanic environment. The mainly turbiditic composition of the easternmost outcrop areas, suggests that their source was a continental margin that provided abundant detrital material to the continental shelf, and perhaps beyond. A deep-sea fan environment was envisaged by Godoy and others (1984) for the turbiditic sequence of the Chonos Archipelago, in view of its sedimentary facies and the interbedded pelagic radiolarian cherts, which would have been generated in fan lobes during inactive periods.

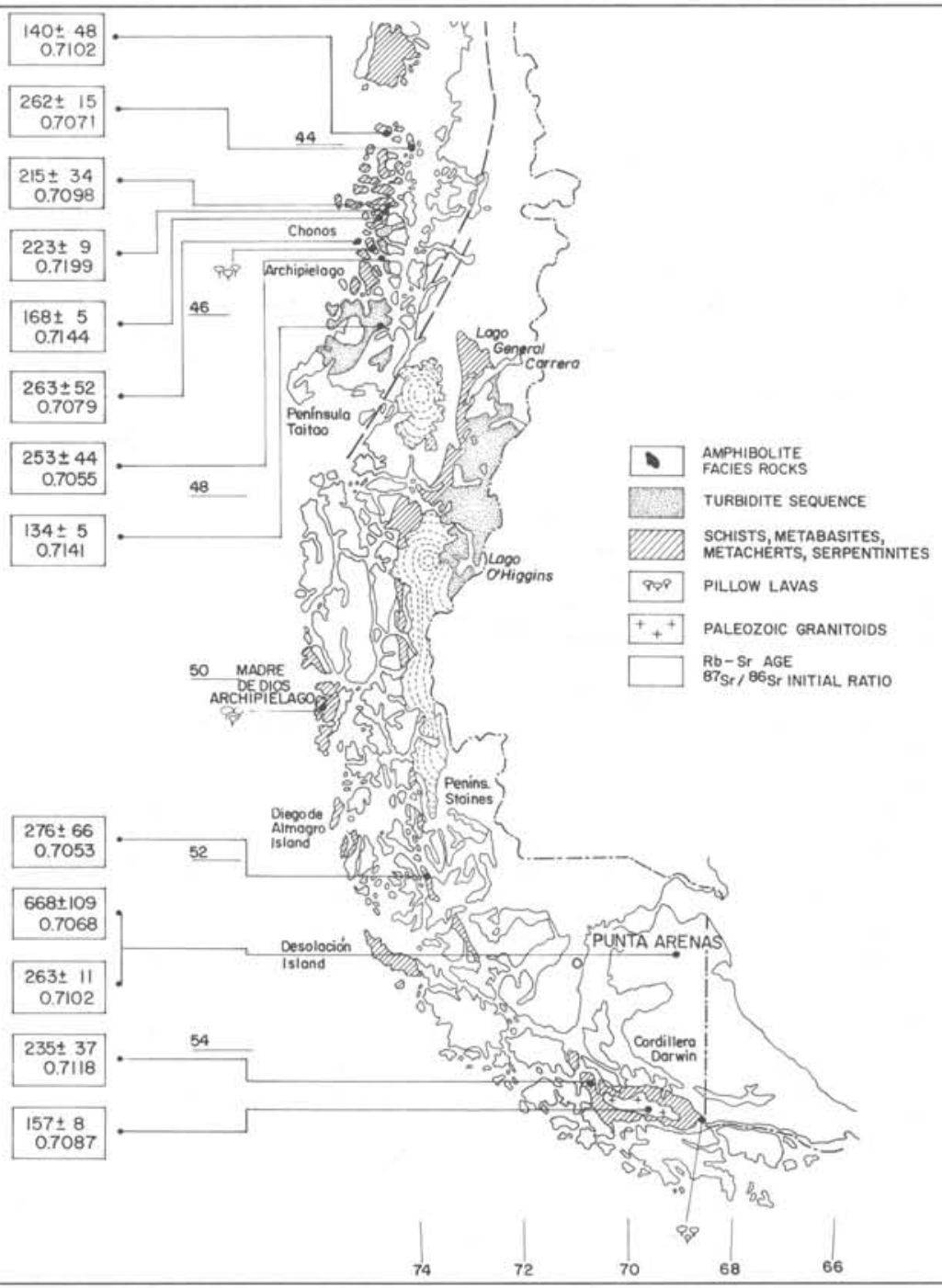

Carboniferous granitoid belt is the eastern limit north of $38^{\circ} \mathrm{S}$, with a strong metamorphic gradient increasing towards it, moving from low-grade biotite-bearing greenschist facies in the west, through continuous andalusite and discontinuous staurolite zones, to high-grade sillimanitecordierite-garnet gneisses. These metamorphic zones are developed in the turbidite sequence rocks, and are devoid of meta-basites across the $20 \mathrm{~km}$ outcrop width.

South of $38^{\circ} \mathrm{S}$, the late Paleozoic granitoids are absent, except for a small massif in the Panguipulli-Riñihue area (east of Valdivia), and the metamorphic complex is intruded by the North Patagonian batholith of Jurassic to Cenozoic age, with only very narrow (500 $\mathrm{m}$ or less) hornfelsic contact aureoles. Biotite and occasional andalusite are char- 


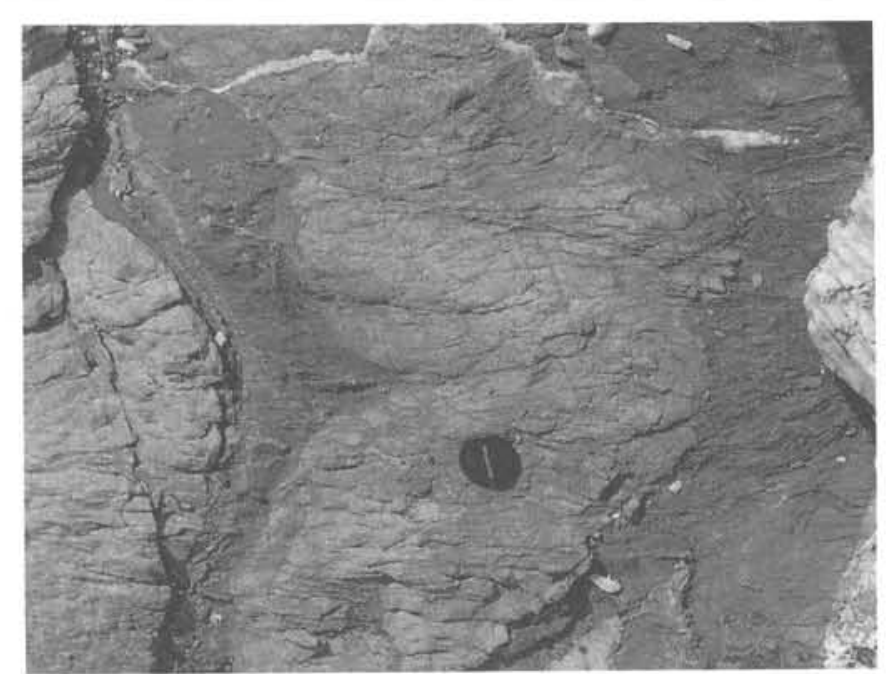

Figure 2: Very low-grade meta-turbidites showing well-preserved bedding, Chonos Archipelago.

acteristic, and staurolite and sillimanite occur sporadically. At Cordillera Darwin, a staurolite-kyanite zone is developed near the contact with a Jurassic pluton.

A regional metamorphic gradient increasing westwards is well developed away from the influence of the granitoids, both in the northern and southern sections. At the Chonos Archipelago there is a continuous increase in the crystallinity of illite from CR (relative crystallinity) 227, indicating very low-grade metamorphic conditions (Garrido, 1987), to $\mathrm{CR} 118$, implying low-grade metamorphism. Deduced temperatures vary from a miniumum of $200^{\circ} \mathrm{C}$ to a maximum of $400^{\circ} \mathrm{C}$. The westernmost areas are typical greenschist facies rocks with the following mineral associations:

- meta-basites: albite-epidote-chlorite-actinolite sphene ( $\pm \mathrm{Na}$ amphiboles),

- mica schists: quartz-albite-chlorite-muscovite tourmaline,

- meta-cherts: quartz-stilpnomelane-magnetite ( \pm Na-amphibole).

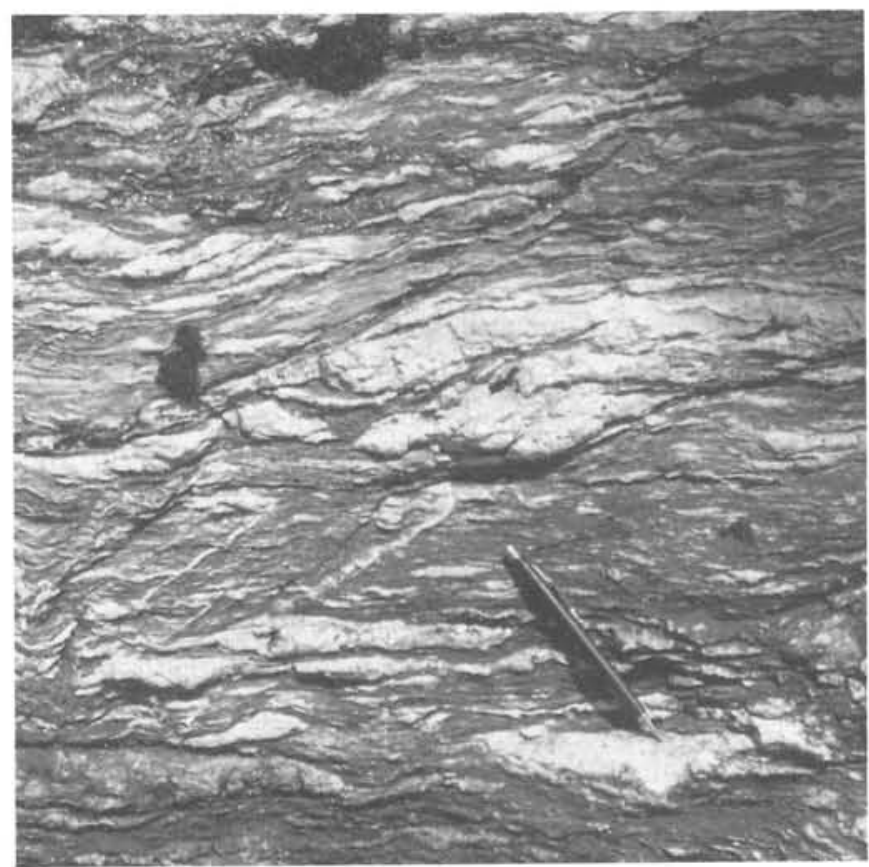

Figure 3: Mélange at Teresa Island in the Chonos Archipelago.

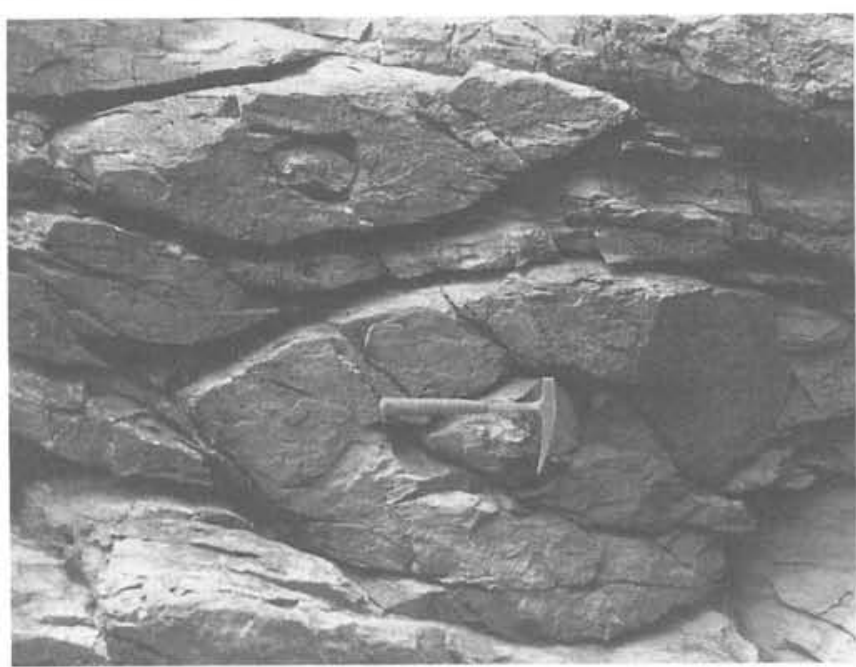

Figure 4: Greenstone with well-preserved pillow structure and geochemically similar to present day ocean floor basalts. Punta de Lobos, $5 \mathrm{~km}$ south of Pichilemu.

Similar mineral assemblages occur in the northern section where sporadic abundant $\mathrm{Na-amphibole} \mathrm{occurs,} \mathrm{as} \mathrm{in} \mathrm{Pich-}$ ilemu. Lawsonite has only been recorded from Chiloé Island (Saliot, 1968), where it is accompanied not by glaucophane but by chlorite and albite. South of the Taitao Peninsula, $\mathrm{Na}$-amphibole has been recorded in otherwise typical greenschist facies assemblages (Forsythe and Mpodozis, 1979). Higher grade rocks containing omphacite are found exclusively as loose boulders in spatial association with a serpentinite body at Los Pabilos $\left(40^{\circ} \mathrm{S}\right.$, Kato, 1985), probably having been tectonically brought to higher levels along with the ultramafic body.

Thus, the rocks of the western parts of the metamorphic complex contain greenschist facies assemblages with some indications of higher pressure minerals. Kato (ibid) has presented evidence that a former high greenschist-lower amphibolite assemblage was present in these rocks near Valdivia. The sphalerite-chalcopyrite geothermometer suggests pressures of $6.5 \pm 2.5 \mathrm{~Kb}$ for the metamorphism of massive sulphides in greenschists near Concepción (Collao et al., 1986).

\section{Structure}

The structure of the complex is well displayed in the Nahuelbuta Mountains and the Chonos Archipelago (Fig. 6). In the former area, the eastern part of the section has the

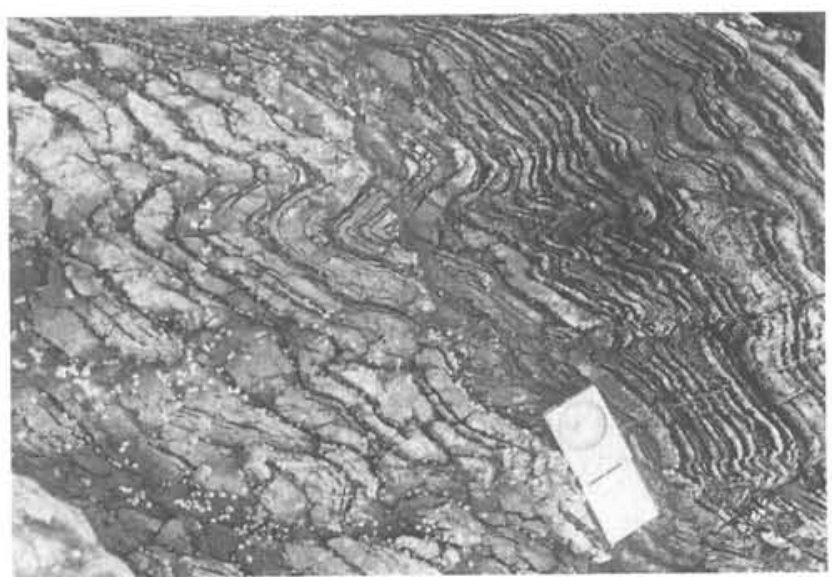

Figure 5: Radiolaria-bearing ribbon cherts at Chalacayec Island, Chonos Archipelago, have geochemical characteristics similar to metalliferous siliceous sediments near modern mid-ocean ridges. 
general shape of a synform with granitoids located in its centre. Primary structures are preserved in the lower grade parts of the series, which are particularly well exposed in the Laraquete area.

The strata are folded into complicated interference patterns. An early $S_{1}$ foliation associated with upright folds and a later $S_{2}$ foliation dipping moderately eastwards are recognized. The granitoids intruded during $\mathrm{S}_{2}$ time. This foliation develops progressively towards the west, making it difficult to recognize $S_{0}$, and leaving $S_{1}$ as rootless isoclinal minor folds in the microlithons bounded by $\mathrm{S}_{2}$. This is the typical structure of the characteristic spotted mica schist all along the Coast Ranges.

At the Chonos Archipelago, the structure of the complex is surprisingly similar in its overall pattern. The easternmost portion is characterized by upright tight folds with a well cherts have yielded Late Carboniferous to Permian ages (Ling and Forsythe, 1987) at Madre de Dios and Early Permian ages at Regalada island $\left(54^{\circ} \mathrm{S}\right)$, supporting the idea of a younging of the deposits from north to south.

As regards radiometric dating of the metamorphic complex, Munizaga and others (1972) interpreted the 270-342 Ma "limiting reference isochrons" as the probable age of metamorphism between $34^{\circ}$ and $38^{\circ} \mathrm{S}$. Further dating of these rocks has produced the $26 \mathrm{Rb}-\mathrm{Sr}$ isochrons (error-chrons) shown in Figure 1, as well as numerous $\mathrm{K}-\mathrm{Ar}$ mineral ages. All the isochrons yield ages between 368 and $140 \mathrm{Ma}$ for the metamorphic complex of the Coast Range south of $34^{\circ} \mathrm{S}$.

The age pattern emerging from these data indicates older ages for the easternmost rocks in any particular east-west profile south of $34^{\circ} \mathrm{S}$. East of Pichilemu, the higher grade sillimanite gneisses are $368 \mathrm{Ma}$ old, the andalusite-staurolite

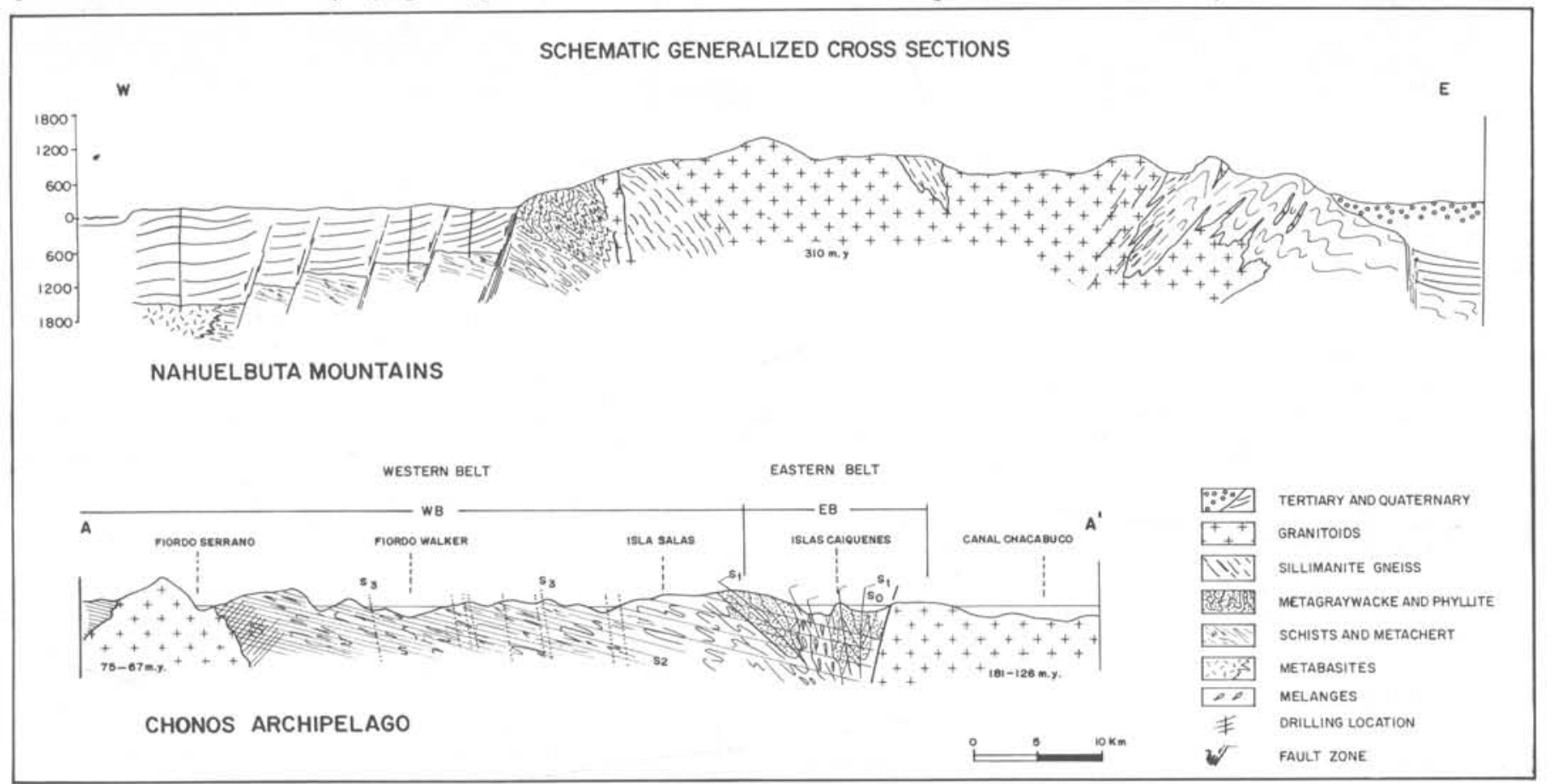

Figure 6: Sections across the metamorphic complexes at Nahuelbuta Mountains $\left(38^{\circ} \mathrm{S}\right)$ and Chonos Archipelago $\left(44^{\circ} \mathrm{S}\right)$.

developed $\mathrm{S}_{1}$ axial-plane cleavage, and mélange areas. A low-dipping $\mathrm{S}_{2}$ erenulation cleavage (Fig. 7) is progressively developed towards the west, where it becomes the predominant structural feature. A big difference between the two areas, however, is that the batholith to the east is here Mesozoic-Cenozoic.

\section{Geochronology}

There are a few indications of the age of deposition of the protolith to the metamorphic complex. At Lumaco, Tavera (1983) described the presence of worm tubes of Gordia? sp and Crossopodia nahuelbutanus sp. nov., which he interpreted as indicating Silurian deposition. Miller and Sprechmann (1978) described Devonian brachiopods from coarse sandstones at Isla Patranca. Apparently these were transported by turbidity eurrents to the deep ocean during the Early Devonian or Late Silurian. At Punta Buill (Chiloé), Levi and others (1966) recorded from rocks not in place trilobites, crinoids, tetracorals and nautiloids, which would indicate a Devonian age.

From Madre de Dios, Douglass and Nestell (1976) described a fusulinid assemblage in massive limestones, indicative of deposition in warm waters during the Permian. Radiolarian rocks west of them have a concordant $347 \pm 32$ Ma metamorphic age and the blueschists at Pichilemu $310 \pm 11 \mathrm{Ma}$. Between Concepción and Valdivia, isochrons range between 290 and $330 \mathrm{Ma}$ for rocks near the coast. The younger Carboniferous ages are thought to represent the age when $\mathrm{S}_{2}$ was generated in the rocks, and phase of increased convergence rate or of sedimentary input into the trench.

At the Chonos Archipelago, older ages also tend to be encountered in the easternmost rocks, in which $S_{1}$ is the predominant structure. Younger ages of $140 \pm 40 \mathrm{Ma}$ and $168 \pm 5 \mathrm{Ma}$ are obtained in more western rocks where $\mathrm{S}_{2}$ is the predominant structure. A complete resetting of the $\mathrm{Rb}$-Sr systems during the development of $\mathrm{S}_{2}$ appears to have taken place, and this age pattern is supported by a few $\mathrm{K}-\mathrm{Ar}$ whole rock age determinations.

South of the Taitao Peninsula, the few determinations include Late Jurassic $\mathrm{K}-\mathrm{Ar}$ ages on glaucophane schists near Madre de Dios. Cretaceous mineral ages and Triassic (235 \pm $37 \mathrm{Ma}$ ) $\mathrm{Rb}-\mathrm{Sr}$ isochrons at Cordillera Darwin (Hervé et al., 1981) tend to support the southward-younging pattern deduced from the few paleontological sites. Thus, the metamorphic complex varies both in the depositional age of the protolith and in its metamorphic age. The former is probably Devonian or Silurian (or earlier?) from the Chonos Archipelago to the north, and Late Carboniferous and Permian south of the Taitao Peninsula. The apparent east 
to west younging of the metamorphism along the belt is in accordance with successive accretion from the west, with upheaval of the rocks after metamorphism.

The ${ }^{87} \mathrm{Sr} /{ }^{86} \mathrm{Sr}$ initial ratios of the rocks in the Pichilemu area indicate higher values $(0.712)$ in the eastern metamorphosed turbidite sequence, in agreement with the idea that the clastic material comes from a continental source in the South American craton. Westerly rocks, including the pillow basalts and meta-cherts, have lower values (0.706), indicating the greater influence of oceanic materials. Still lower values $(0.704-0.705)$ are obtained from the meta-basites and meta-pelites associated with the massive sulphides in the Temuco-Valdivia area. Assuming no metasomatic processes during their metamorphism, and a ${ }^{87} \mathrm{Sr} /{ }^{86} \mathrm{Sr}$ value of 0.7025 for the upper mantle from which these rocks were derived, a maximum age for the basaltic protolith would be around $400 \mathrm{Ma}$, that is Silurian.

\section{Geological Evolution}

The metamorphic complex of the Coast Ranges of central and southern Chile records geological processes along the south and southwestern margin of Gondwana during the late Paleozoic. Thick turbidite sequences accumulated on the ocean floor adjacent to the continent, probably from as early as the Silurian but mainly, it seems, during the Devonian. These thick sedimentary detrital sequences of continental origin indicate the presence of an emerging continent with active erosional and sediment transport processes towards the fringing ocean. The absence of Silurian or Devonian granitoid belts suggests that subduction processes were not very active during these periods: a passive type of continental margin may have existed here.

The pelagic sequence was accreted to the continent before the Early Carboniferous in the north and after the Early Permian in the south, during a constructive phase of the accretionary prism (Davidson et al., 1987). Mélanges developed between tectonic wedges of turbidite material. During this phase, oceanic rocks were incorporated into the accretionary prism from the west, representing either material generated at oceanic ridges or island ares, or tectonic slices of the ocean floor supporting the turbidite sequence. These oceanic rocks were metamorphosed in the accretionary prism, and low initial $\mathrm{Sr}$ ratios indicate that the time of the extrusion of pillow basalts was not much earlier than their metamorphism. The easternmost and probably thickest part of the accretionary sequence was affected by a long low-PT metamorphism, beginning in the north.

In the Late Carboniferous, the tectonic regime changed dramatically in the north, giving rise to the development of higher PT metamorphism and high strain during the generation of $\mathrm{S}_{2}$. This "destructive phase" on the accretionary prism may correspond to an increase in shear strain along the base of the accretionary prism, a phenomenon that could have been enhanced by a faster convergence rate, a reduced sedimentary input or a decrease in pore pressure that resulted in a strong mechanical coupling between the oceanic plate and the accretionary wedge. At this stage, the tectonic conditions led to burial of the rocks deep in the lithosphere, giving rise to processes culminating in the generation of the huge late Paleozoic magmatic belt. This belt turns westward around $38^{\circ} \mathrm{S}$, trending southeastwards along northern Patagonia, tracing out the old continental margin.

The same process was active in the southern part on the complex after the Permian, as indicated by the involvement of rocks of that age in the accretionary wedge, and perhaps into the Jurassic, as indicated by the $\mathrm{Rb}-\mathrm{Sr}$ isochrons at the Chonos Archipelago. A special tectonic situation existed in Cordillera Darwin with the generation of an aborted ocean- floored marginal basin, which allowed Cretaceous metamorphism to take place affecting previously metamorphosed rocks of the subduction complex.

The constructive phase of the subduction complex involved the generation of a wide area of accreted material, including island ares and sedimentary deposits of intervening basins. This is a situation similar to the present day Western Pacific margin, where complicated patterns of island ares and ocean ridges contrast with the simple linear volcanic belt of South America. The characteristics of the late Paleozoic environment in Chile could be described as those of a Mariana-type continental margin during the "constructive" phase of an accretionary prism. The change of regime to a destructive phase of the accretionary prism, marked by the generation of the $\mathrm{S}_{2}$ foliation and the intrusion of the granitoids, might be the record of the initiation of a Chilean-type regime for the continental margin in the classification of Uyeda (1982).

After the diachronous high-PT metamorphism, the metamorphic complex was rapidly uplifted and eroded to levels similar to the present exposures by Late Triassic times in the north and probably by the Early Cretaceous in the south. K-Ar mineral ages are only a little younger than the $\mathrm{Rb}-\mathrm{Sr}$ isochron ages, probably indicating rapid uplift just after the generation of $\mathrm{S}_{2}$. The accretion was displaced westwards so that along the present coastline no outcrops of a Cenozoic accretionary complex exist. If present, they are offshore, in contrast to the situation in Barbados and some island ares of the west Pacific where late Cenozoic aceretionary prisms outcrop. Munizaga and others (in press) suggest that tectonic erosion of the continental margin in the northern part of the complex took place from the Mesozoic to the Cenozoic.

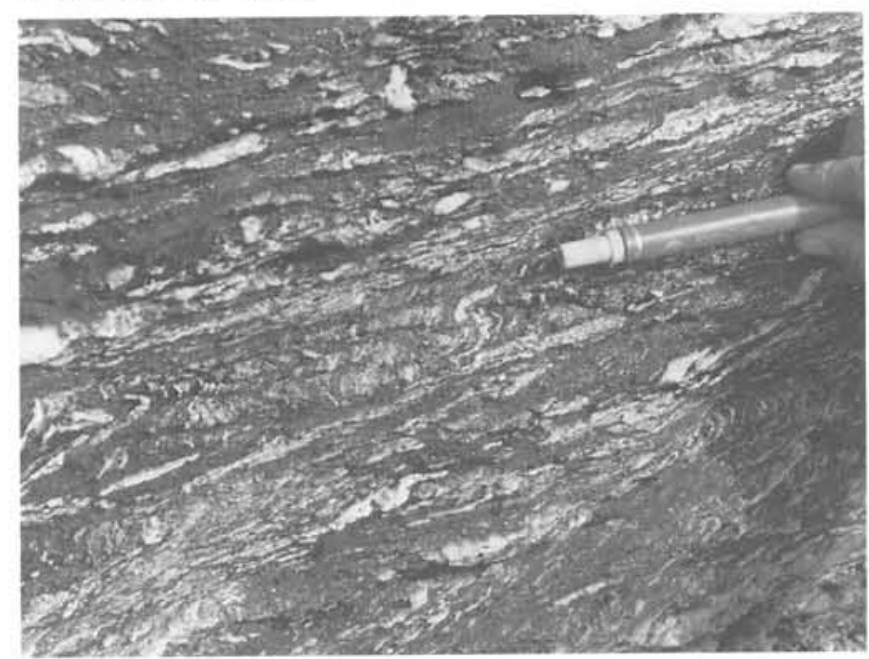

Figure 7: Crenulation cleavage $\left(S_{2}\right)$ in banded phyllite at Teresa Island, Chonos Archipelago.

The metamorphic complex of the Coast Ranges of southcentral Chile probably originated by subduction and accretion from west to east, related to the consumption of a proto-Pacific Oceanic plate. However, little is known about the later history of displacement of the subduction complex once it was incorporated to the continental overriding plate. Recent paleomagnetic studies around the LiquiñeOfqui megafault (García, 1987), which extends to the east of the Coast Range between 39 and $45^{\circ} \mathrm{S}$ have shown that 400 to $500 \mathrm{~km}$ of dextral strike-slip movement might have occurred along it, displacing the coastal metamorphic complex northward.

It is interesting to point out that at this latitude, rocks similar to those outcropping in the coastal areas appear at Lago General Carrera (Fig. 1), in an anomalous position to 
the general organization of the complex. This might, perhaps, be the result of doubling the complex by oblique slicing and northwards transport of the western slice along the continental margin. However, this is one problem to be resolved before confident paleogeographic reconstructions for the late Paleozoic for the area can be produced.

\section{Acknowledgements}

The results presented here were made possible by Grant E-2457 of the Departamento de Investigación y Bibliotecas of the University of Chile, and 1332 of FONDECYT, as well as field and laboratory work and discussion with several colleagues including Estanislao Godoy, Constantino Mpodozis, John Davidson, Robert Pankhurst, Maureen Brook, Koji Kawashita, Umberto Cordani, Hubert Miller and Francisco Munizaga. Grants from JICA (Japan), the Guggenheim Foundation and the Royal Society of London have allowed the author access to modern laboratories abroad and to multinational friendship.

Prof. F. Hervé teaches metamorphic petrology in the Department of Geology and Geophysics of the Universidad de Chile (Casilla 13518, Correo 21, Santiago, Chile). A graduate of the Université de Paris and Hokkaido University of Japan, he works on the metamorphic complexes of southern Chile and west Antarctica.

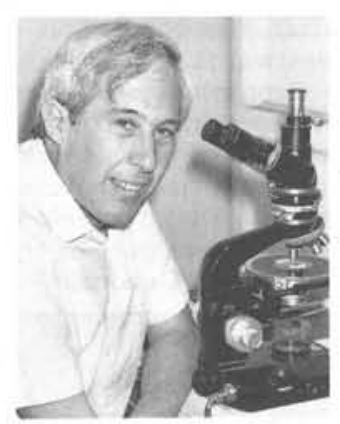

\section{References}

Anon., 1960. Carta Geológica de Chile 1:1,000,000, Instituto de Investigaciones Geológicas, Santiago.

Collao, S., Kojina, S. and Oyarzun, R., 1986. Geobarometría de los sulfuros macizos de la franja metamórfica de esquistos verdes, Chile Central Sur. Revista Geológica de Chile, Santiago, no. 28-29, p. 3-16.

Davidson, J., Mpodozis, C., Godoy, E., Hervé, F., Pankhurst, R. and Brook, M., 1987. Late Paleozoic accretionary complexes on the Gondwana margin of southern Chile: Evidence from the Chonos Archipelago. In: MeKenzie, G.D. (ed.), Gondwana Six: Structure, Tectonics and Geophysics. Geophysical Monograph Series 40, p. 221-227.

Douglass, R.C. and Nestell, M.K., 1972. Late Paleozoic Foraminifera from southern Chile. U.S. Geological Survey Professional Paper 858, 49 p.

Forsythe, R. and Mpodozis, C., 1979. El Archipiélago Madre de Dios, Patagonia Occidental, Magallanes: rasgos generales de la estratigrafia y estructura de "Basamento" prejurasico superior. Revista Geológica de Chile, v. 7, p. 13-29.

Forsythe, R. and Mpodozis, C., 1983. Geología del basamento prejurasico superior en el Archipiélago Madre de Dios, Magallanes, Chile. Boletin Servicio Nacional de Geología y Mineria, Santiago, v. 39, 63p.

Gana, P. and Hervé, F., 1983. Geología del basamento cristalino en la cordillera de la costa entre los rios Mataquito y Maule, VII Region. Revista Geologica de Chile, no. 19-20, p. 37-56.

García, A., 1986. Paleomagnetic reconnaissance of the "Region de los Lagos," southern Chile, and its tectonic implications. M.Sc. thesis, Western Washing ton University, U.S.A.

Garrido, L., 1987. Geología y petrología de Isla Teresa, Archipiélago de los Chonos, Aysen. La eristalinidad de la illitacomo indicador de grado metamor fico. Memoria de título, Universidad de Chile, Departamento de Geología, Santiago, $117 \mathrm{p}$.

Godoy, E., 1979. Metabasitas del basamento metamórfico chileno. Nuevos datos geoquímicos. In: Suarez, M. (ed.), Actas, 2nd Congreso Geológíco Chileno, v. 3, p. E133-E148, Arica.

Godoy, E., 1980. Zur Geochemie der Grünschiefer des Grundgebirges in Chile. Muensterische Forschungen zur Geologie und Palaeontologie, no. 51, p. 161-182.

Godoy, E., 1986. Die Entwicklung des Gondwana-Randes in Chile während des Paläozoikums unter besonderer Berucksichtung der geotektonischen Stellung der Metavulkanite. Dissertation Universität Münster, 70p., Germany.

Godoy, E., Davidson, J., Hervé, F., Mpodozis, C. and K. Kawashita., 1984. Deformación sobreimpuesta y metamorfismo progresivo en un prisma de acre- eión paleozoico: Archipiélago de los Chonos, Aysén, Chile. Actas IX Congreso Geológico Argentino, v. 4, p. 211-232.

González-Bonorino, F., 1971. Metamorphism of the crystalline basement of central Chile. Journal of Petrology, no. 12/1, p. 149-175.

González-Bonorino, F. and Aguirre, L., 1970. Metamorphic facies series of the crystalline basement of Chile. Geologische Rundschau, v. 59, no. 3, p. 979-994. Harrington, H.J., 1962. Paleogeographic development of South America. American Association of Petroleum Geologists Bulletin, v. 46, no. 10, p. $1773-1814$

Hervé, F., 1977. Petrology of the crystalline basement of the Nahuelbuta Mountains, south central Chile. In: Ishikawa, T. and Aguirre, L. (eds.), Comparative studies on the Geology of the Circum-Pacific Orogenic Belt in Japan and Chile, Ist Report, Tokyo, p. 1-51.

Hervé, F., Godoy, E., Ojeda, J.M. and del Campo, M., 1976. Las metabasitas del basamento metamórfico de Chile central y austral. Actas, I Congreso Geológico Chileno, v. 2, p. F175-F187.

Hervé, F., Munizaga, F., Godoy, E. and Aguirre, L., 1974. Late Paleozoic K/Ar ages of blueschists from Pichilemu, central Chile. Earth and Planetary Science Letters, v. 23 , no. 2, p. 261-264.

Hervé, F., Munizaga, F., Mantovani, M. and Hervé, M., 1976. Edades Rb-Sr neopaleozoicas del basamento cristalino de la Condillera de Nahuelbuts. Actas, I Congreso Geológico Chileno, v. 2, p. F19-F26.

Hervé, F., Nelson, E., Kawashita, K. and Suarez, M., 1981. New isotopic ages and the timing of orogenic events in the Cordillers Darwin, southernmost Chilean Andes. Earth and Planetary Science Letters, v. 55, p. 257-265.

Kato, T.T., 1985. Pre-andean orogenesis in the Coast Ranges of central Chile. Geological Society of America Bulletin, v. 96., no. 7, p. 918-924.

Levi, B., Aguilar, A. and Fuenzalida, R., 1966. Reconocimiento geológico en las provineias de Llanquihue y Chiloé. Instituto de Investigaciones Geológicas Boletin 19, IIG, 45 p., Santiago.

Ling, H.Y. and Forsythe, R.D., 1987. Late Paleozoic pseudoalbaillellid radiolarians from southernmost Chile and their geological significant. In: MeKenzie, G.D., (ed.), Gondwana Six: Structure, Tectonies and Geophysics, AGU Geophysical Monograph 40, p. 253-260, Washington.

Miller, H. and Sprechmann, P., 1978. Eine devonische Faunula aus dem Chonos-Archipel, Region Aisén, Chile, und ihere stratigraphische Bedeutung. Geologisehes Jahrbuch, B28, p. 37-45.

Miyashiro, A., 1961. Evolution of metamorphic belts. Journal of Petrology, v, 2, no. 3, p. 277-311.

Munizaga, F., 1967. Geocronología de los esquistos del Sur de Chile. Abstract, Jornadas IIG, X Anniversary, Santiago, p. 36-37.

Munizaga, F., Aguirre, L. and Hervé, F., 1973. Rb-Sr ages of rocks from the Chilean metamorphic basement. Earth and Planetary Science Letters, v. 18, p. $87-92$.

Munizaga, F., Hervé, F., Brook, M., Pankhurst, R.J., Snelling, N.J. and Drake, $R$., in press. Geochronology of the granitoids of the lake region of south central Chile $\left(38^{\circ}-41^{\circ} \mathrm{S}\right)$. Preliminary Results. Journal of South American Earth Sciences.

Muñoz-Cristi, J., 1964. Estudios petrográficos y petrológicos sobre el batolito de la costa de las Provincias de Santiago y Valparaiso. Instítuto de Geología, Universidad de Chile, Santiago, no. 25, 93p.

Ojeda, J.M., 1976. Estudio petrológico y estruetural del basamento metamórfico y de la serpentínita de Morro Bonifacio, Valdivia. Memoria de título, Universidad de Chile, Departmamento de Geología, Santiago.

Ruiz, C., 1965. Geología y yacimientos metalfferos de Chile. Instituto de Investigaciones Geologicas, Santiago, 385p.

Saliot, P., 1968. Sur la presence et al signification de la lawsonite dans la Condillere cotiere du Chili (ne de Chiloe). Comptes Rendus des Seances de l'Academie des Sciences, Serie D., no. 267, p. 1183-1185.

Tavera, Ja, 1983. Noticia sobre la presencia de Graptoloideos en rocas del basamento cristalino In: Contribucion al conocimiento del Cuaternario chileno. Imp. grafica, Santiago, 20p.

Uyeda, S., 1982. Subduction zones: an introduction to comparative subductology. Tectonophysics, v. 81, no. 3-4, p. 133-159.

Zuecone, A., 1988. Los placeres aurfferos de Madre de Dios. Taller de Título II, Universidad de Chile, Departamento de Geologia, Santiago, unpublished report. 